\title{
Contribution Of Infrastructure Facilities Towards The Enhancement Of Students' Learning Outcomes
}

\author{
Ade Fitri Rahmadani \\ Pendidikan Teknik Informatika dan Komputer, Universitas Bung Hatta, Indonesia \\ e-mail : adefitri.rahmadani@bunghatta.ac.id
}

\begin{abstract}
This research intends to show the contribution of infrastructure facilities towards the outcomes from "Mediagnosis Permasalahan Pengoprasian PC dan Peripheral" class on students with specification. The method of this research is descriptive correlational. The data comes from the questionnaire that were spread, with scale model of likert, which comes with five answer scales. With total of 105 population, which all from $\mathrm{X}$ grader students majoring in Computer Network Engineering; using the random sampling technique, 53 students were picked. The questionnaire was analyzed using the SPSS (Statistic Product and Service Solution) 16.0 program. The outcome of data processing was that the analysis uji-t of thitung was 6,233 , which there was a correlation of contribution of facilities towards learning outcomes. Meanwhile, ttabel was 2,008 with df $=\mathrm{n}-2$ at a significance level of 0,05 with the provisions of thitung $>$ ttabel. This means that the correlation of the facilities and learning outcomes is as big as $43,2 \%$, while the other factors are affected from other variables.
\end{abstract}

\section{Introduction}

Education is a system which includes input, process and output. As Arikunto (2009) said, input is a raw ingredient which inserted to transformation. In school system, 'raw ingredient' means the student candidates who are just about to enter school. Before these students enter an institution or school, their abilities would be assessed first. The scores would indicate whether or not the student would do well in school.

These students' scores could be measured by their abilities and process of learning. According to Arikunto (2012), learning outcomes are the results that the students get from their processes of learning, so that their abilities could be measured by their own learning outcomes.

Students' abilities that could be measured by their process of learning could also influenced by two factors, which are internal and external (Slameto, 2010). Internal is a factor which is in someone's body. In this case, internal factor includes interest, talent, motivation, memory, intelligence, and creativity; meanwhile, the external factor includes the environment, like family, friends, and school environment.

Educational facilities include in the external factor that would influence the outcomes of learning. These educational facilities could be the tools and equipment that students use at 
school; however, all these equipment could be the reason why the learning outcomes are not optimal (Bafadal, 2008: 2).

From the observation that was held in the vocational high school, there was an indicator that shows how low the learning outcomes were, which caused by lack of facilities. For example, the amount pf computers in the computer room were not enough for 35 students with only 2 hours period a week. This situation makes the graduating students have not been able to compete in a workplace setting and also have not been able to create their own business because of how limited the lab equipment is; therefore, this situation makes the students have not been able to grow in their own field of interest and have not been able to reach the 'Kriteria Ketuntasan Minimum' or KKM from the subjects that have been set.

\section{RESEARCH METHOD}

This research is a descriptive correlation research. The population includes 105 students which were picked with Proportional Random Sampling method; this method is suitable with the sampling technique, which then obtained a sample of 52 students. Then, each sample got separated by 3 classes using the formula from Sugiyono that was shown by Ridwan (2010):

$$
n_{i}=\frac{N_{i}}{N} \cdot n
$$

So, the total sample that was used in this research is 53 students, while the rest of the sample would be used in the trial instrument. The sample respondents in this instrument trial were students who were not included in the sampling and in the actual data retrieval.

Questionnaire is the instrument that was picked to get the data for this research; every question in the questionnaire has a value that was set in the likert scale model, which has five scales in each question, which are 'Selalu' or SL, 'Sering' or SR, 'Kadang-kadang' or KD, 'Jarang' or JR, and 'Tidak Pernah' or TP. Each question has its value from 1 to 5; if the question either tend to be positive or negative, each question has the value of either 1 , $2,3,4$ or 5 .

\section{RESULTS AND DISCUSSION}

The variable data of the facilities was picked by the questionnaire that had 25 questions and have been checked each one of their validity and reliability. The valid questionnaire will be tested to those 53 sample respondents. The description of the distribution of infrastructure infrastructure scores can be seen in table 1 below:

Table 1. Distribution of Infrastructure Score Variable Score

\begin{tabular}{lll}
\hline Kelas Interval & Frekwensi & Persentase (\%) \\
\hline $69-74$ & 3 & $5.66 \%$ \\
\hline $75-80$ & 6 & $11.32 \%$ \\
\hline $81-86$ & 9 & $16.98 \%$ \\
\hline $87-92$ & 11 & $20.75 \%$ \\
\hline $93-98$ & 8 & $15.09 \%$ \\
\hline $99-104$ & 13 & $24.52 \%$ \\
\hline $105-110$ & 3 & $6.66 \%$ \\
\hline Total & 53 & $100 \%$ \\
\hline
\end{tabular}


From the data obtained, the average level of achievement score of vocational student infrastructure facilities amounted to $83.07 \%$, and entered into the category very strong.

The result of product moment correlation from pearson can be seen in table 2 below:

Table 2. Product Moment Correlation with SPSS

\begin{tabular}{lcc}
\hline Variable & Pearson Correlation & Significance \\
\hline $\mathrm{X} 1-\mathrm{Y}$ & .658 & .000 \\
\hline
\end{tabular}

According to the correlation of the simple analysis in table 2, there is a correlation between facilities and the students' learning outcomes (r) which is 0,658 . This shows that there is a strong relation between infrastructure facilities with the learning outcomes, because it falls between $0,60-0,799$, with positive direction because of the $r$ value is positive, therefore, the complete the facilities, the more positive the outcome.

Then, the analysis of significance test to see the significance of the correlation or significance relationship of two variables. According to Ridwan (2009), to test the significance of one independent variable with dependent variable used t calculation formula that can be seen in table 3 below:

Table 3. Uji -t

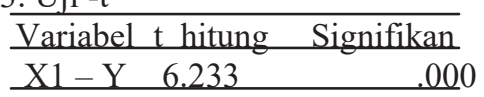

The result of uji-t is thitung $=6,233$ and ttable $=2,008$, with $\mathrm{df}=\mathrm{n}-2$, which can also be said that thitung $(6,233)>$ ttable $(2,008)$, or significance $<$ alpha $(0.000<0,05)$; H0 got rejected, while $\mathrm{H} 1$ got accepted, meaning that there is a correlation infrastructure facilities (X1) towards the outcome of student learning (Y).

After the t-test is done, then the last thing that needs to be done is the determination analysis to find the percentage of the correlation between facilities and the outcome of learning, which can be seen in table 4 below:

Table 4. Analisis Determinasi

\begin{tabular}{lc}
\hline Variabel & r Square \\
\hline $\mathrm{X} 1-\mathrm{Y}$ & .432 \\
\hline
\end{tabular}

According to the table number 4 , the $\mathrm{r} 2$ ( $\mathrm{r}$ square) is as big as 0,432 , therefore the total contribution of the facilities towards the outcome of learning could be seen in the Koefisien Determinan (KP) score, which $0,432 \times 100 \%=43,2 \%$. This shows the percentage contributes the facilities towards the outcome is $43,2 \%$, while the rest is from other variables.

\section{SUMMARY AND RECOMMENDATION}

\subsection{Summary}

Infrastructure facilities have a significance contribution towards the learning outcomes of vocational student, which is $43,2 \%$ with $95 \%$ of confidence level. This shows that the better the facilities, the better the learning outcomes for these students. 


\subsection{Recommendation}

The researchers are expected to study more deeply about other factors that have an influence on learning outcomes. Thus, efforts to improve student learning outcomes can be implemented in a real way. Other than that, the school is expected to add more facilities in school to boost up the outcome of student learning, that would automatically boost up the percentage of graduating students. And to the further researchers, to further expand the study of the factors that affect learning outcomes in terms of aspects studied, the number of respondents, as well as the area of research, because there are still many factors that affect the student learning outcomes that have not been revealed in this study.

\section{Acknowledgement}

This article was included in thesis paper when the writer was only a college student strata 1 in Engineering Department of Padang State University. This article has already made it through the seminar and also tested by the professors in Padang State University.

\section{References}

1. Arikunto, Suharsimi. 2002. Prosedur Penelitian Suatu Pendekatan Praktek. Jakarta: Rieneka Cipta.

2. Arikonto, Suharsimi . 2009. Dasar-Dasar Evaluasi Pendidikan, Jakarta: Bumi Aksara. Edisi Revisi.

3. Ibrahim, Bafadal. 2008. Manajemen Perlengkapan Sekolah Teori dan Aplikasinya. Jakarta: Bumi Aksara.

4. Riduwan. 2010. Dasar-dasar Statistika. Bandung: Alfabeta.

5. Slameto. 2010. Belajar dan Faktor-Faktor yang Mempengaruhinya. Jakarta: Rieneka Cipta.

6. Sukardi. 2009. Metodologi Penelitian Pendidikan. Jakarta: PT. Bumi Aksara. 